\title{
Human Capital Development and Industrialization in Nigeria: Implication for Economic Growth
}

Desarrollo del capital humano e industrialización en Nigeria: Implicaciones para el crecimiento económico

Jimoh Saka

Lagos State University - Nigeria

Lagos, Nigeria

Saka.jimoh@lasu.edu.ng

Dayo Benedict Olanipekun

Ekiti State University - Nigeria

Ado-Ekiti, Nigeria

dayo626@yahoo.com

\section{Abstract}

This paper examines the role that human capital plays in the relationship between the industrialization process and growth in Nigeria spanning the period 1980 to 2016. The theoretical framework is rooted in one of the new growth theories traceable to Lucas (1988) with emphasis on human capital's role in growth. Through some modifications, we result in two simultaneous equation models, one with growth as a dependent variable and the other, industrialization as a dependent variable. Human capital is disaggregated into male and female literacy rates, male and female life expectancies and other control variables used to explain the growth and industrialization process. The Two-Stage Least Squares adopted gives the expected outcome in most cases for the two model estimations. It is shown that the industrialization process is germane for economic growth, and likewise, male literacy rates can complement the industrial process to improve growth. In the same vein, stable growth facilitates the process of industrialization while human capital variables too play a relevant role in the same process. Identification of the workings of the Nigerian state would be a good foundation for the step towards ameliorating the problems of capacity building and industrialization in Nigeria.

Key Words: Human Capital; industrialization; Growth; Two Stage Least Square

\section{Resumen}

Este trabajo examina el papel que desempeña el capital humano en la relación entre el proceso de industrialización y el crecimiento en Nigeria durante el período comprendido entre 1980 y 2016. El marco teórico se basa en una de las nuevas teorías del crecimiento que se remontan a Lucas (1988), con énfasis en el papel del capital humano en el crecimiento. Mediante algunas modificaciones, se obtienen dos modelos de ecuaciones simultáneas, uno con el crecimiento como variable dependiente y el otro, con la industrialización como variable dependiente. El capital humano se desglosa en tasas de alfabetización masculina y femenina, esperanza de vida masculina y femenina y otras variables de control utilizadas para explicar el proceso de crecimiento e industrialización. Los mínimos cuadrados de dos etapas adoptados dan el resultado esperado en la mayoría de los casos para las estimaciones de los dos modelos. Se demuestra que el proceso de industrialización es determinante para el crecimiento económico y, asimismo, las tasas de alfabetización masculina pueden complementar el proceso industrial para mejorar el crecimiento. En la misma línea, el crecimiento estable facilita el proceso de industrialización, mientras que las variables de capital humano también desempeñan un papel relevante en el mismo proceso. La identificación del funcionamiento del Estado nigeriano sería una buena base para el paso hacia la mejora de los problemas de creación de capacidad e industrialización en Nigeria.

Palabras clave: Capital humano; industrialización; crecimiento; mínimos cuadrados en dos etapas 


\section{Introduction}

Theories and empirical studies have shown a strong link among human capital, industrialization and growth particularly in the modern world with the notion that human capital development plays a significant role during the industrial revolution. Based on Galor (2005), the European region is characterised by a less important contribution of human capital in the process of production during the first phase of industrial revolution and further pointing out that education was useful in the religion, social and national goals attainment. The basis for this argument was that the knowledge acquired through education or skills by an average work force enhances productivity which in turn fosters economic growth. Continuous emphasis on this fails to popularise the role of science and entrepreneurship in the distribution of skills.

Recent research on contemporaneous economies takes into cognisance the importance of education in the attainment of entrepreneurial skills for industrial development (Hanushek and Kimko, 2000; Gennaidi, Porta, Lopez-de-Silanea and Shleifer, 2013). Understanding the link between human capital development and industrialization becomes paramount for economic growth process and more importantly, human development creates the channel through which expansions of people's capabilities could give rise to opportunities for economic empowerment.

Nigeria faces a wide range of human capital challenges, including low primary school enrolment rate globally (65\%), a high incidence of child labour, a low tertiary education attainment rate of 25-54 age group and a low quality of staff training rate (Human Capital Report, 2016). These challenges have made the country to be ranked low in human capital development and literacy rate at the World Economic Forum in 2016. Since the last two decades, Nigeria has remained low in the world's human capital index compared to the developed countries. For instance, in 2016, Nigeria human capital index was 48.86 compared to Finland and Norway that recorded 85.86 and 84.64, respectively (Human Capital Report, 2016). The low ranking recorded in Nigeria is due to inadequate technical know-how resulting in shortage of the required skill needed in specific stage of production.

Consequently, the performance of the Nigeria's industrial sector has not been encouraging over time as its contribution to the Gross Domestic Product (GDP) has been grossly inadequate. For instance, from 2005 to 2014, the share of the industrial sector in GDP fell from 28.3\% to 20.7\%. Since early 1960s, Nigeria's government embraced several national development plans. In the first plan, government focused on Import Substitution Industrialization (ISI). A major part of the first national plan was to mobilize the national economic resources and directed them to achieve industrial development. Subsequent national development plans were geared towards local production of intermediate and capital goods to promote industrial development and stimulate growth. However, most of these initiatives failed to achieve desired result due to low technological capacity, poor infrastructure development and low human capital development (Chete et al, 2016).

This paper is justified by clearly demonstrating the link between human capital development and industrialization and the role the former plays in industrialization-economic growth relationship. Again, the use of Two-stage Least Squares technique enables us to correct for the correlation of errors in the regression, hence, it produces a more reliable results. This is a deviation from most studies in this area. Following the stated problems, the research question that can be drawn include; does gender composition of human capital affect the relationship between industrialization and growth in Nigeria? Does gender composition in human capital complements or substitute industrial process and growth?

1.1 An Overview of Human Capital Development, Industrialization and Economic Growth in Nigeria

\subsubsection{Human Capital Development in Nigeria}

Nigeria's government in collaboration with international agencies had made efforts to achieve 
a high level of human capital development. Essentially, the development of human capital promotes industrialization and growt; this channel seems to be extremely important for education at all levels. Human capital enables the absorption of superior technologies from leading countries (Barro, 2001).

Figure 1 shows the trends in literacy rate and government expenditure on education in Nigeria. For the purpose comparison, the trends in male and female literacy rates are depicted. In all the years, male literacy rate is higher than female literacy rate with an average difference of $20 \%$. In the 1980 male literacy rate ranged from $53 \%$ to $55 \%$ and female literacy rate was between $30 \%$ and $35 \%$.

In 1999, Nigerian government in line with its initiatives of "education for all" re-launched the Universal Basic Education (UBE). At this time, UBE programs were extended to include students in the Junior Secondary School (JSS). Thereafter, the literacy rate increased to $68 \%$ for male and $45 \%$ for female in 2005. In the last decade, male literacy rate increased marginally, on average, it was $69 \%$. An appreciable increase of $5 \%$ in female literacy rate was recorded in 2016 (see figure 1). Available statistics shows that female literacy rate in 2016 stood at $50 \%$ due to reorientation of Nigerians by government, non-governmental organization and international agencies on girlchild education. Nonetheless, human capital development policies in Nigeria are yet to reduce the disparity between male and female sexes.

In 1980 a and 1990s, government expenditure on education was very low (less than $\mathrm{N}_{50}$ billion). The ratio of the public expenditure on education to GDP was less than $2 \%$. Nonetheless, improvement was recorded thereafter following Federal Government education for all policy. Although government expenditure on education showed a steady increase from 2000 to 2013, recent statistics show decline between 2014 and 2016. In the last 10 years, government budget for education has significantly improved but still below the UNESCO recommendation. For example, in 2016 the share of education in total budget was $9 \%$ far below the $26 \%$ recommended by UNESCO demonstrating a $17 \%$ point difference.

Figure 1. Literacy Rate and Government Expenditure on Education in Nigeria

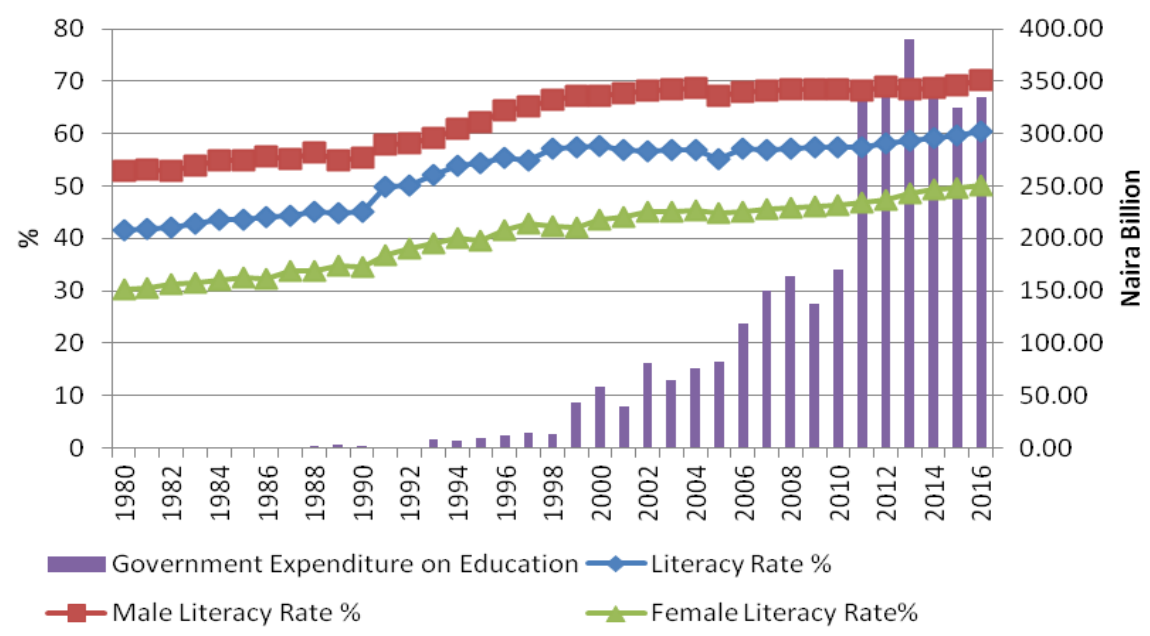

Source: Authors' derivation based on data from World Development Indicator

Human capital development in Nigeria can also be assessed based on enrolment in primary, secondary and tertiary' education. Table1 shows secondary enrolment rates in Nigeria and some selected developing and developed countries. The statistics of secondary school enrolment in Nigeria reflects low human capital development. For instance, between 1980 and 1984 secondary school enrolment rate was $15.3 \%$; this figure is quite low compared to some Africa countries and

1 Due to inadequacy of data, tertiary enrollment would not be examined 
the United States (WDI, 2016). The enrolment rate in Egypt was 52.5\% and United States was 92.2\% (see table 2). Although the rate of secondary school enrolment in Nigeria rose between 1985 and 1989 to 26.5\%; this figure later declined between 1990 and 1994 to 23.89. An assessment of the secondary school enrolment in Nigeria compared to other developing and developed countries show that on average, Nigeria has recorded a low rate of enrolment (less than 55\%) as against $92.8 \%$ in Mauritius and $97.6 \%$ in United States in 2015 (WDI, 2016).Although, most of the government policies yield positive results, secondary school enrolment rate in Nigeria is still far below most developing countries.

Table 1. Secondary School Enrolment Rates in Nigeria and Some Selected Countries

\begin{tabular}{lllllllll}
\hline Country & $\mathbf{1 9 8 0 - 8 4}$ & $\mathbf{1 9 8 5 - 8 9}$ & $\mathbf{1 9 9 0 - 9 4}$ & $\mathbf{1 9 9 5}-\mathbf{9 9}$ & $\mathbf{2 0 0 0}-\mathbf{0 4}$ & $\mathbf{2 0 0 5}-\mathbf{0 9}$ & $\mathbf{2 0 1 0}-\mathbf{1 4}$ & $\mathbf{2 0 1 5}$ \\
\hline Egypt & 52.53 & 62.60 & 72.94 & 74.02 & 81.00 & 68.79 & 81.73 & $\mathrm{~N} / \mathrm{A}$ \\
Ghana & 39.19 & 37.42 & 35.95 & 35.75 & 36.16 & 45.62 & 46.89 & 61.41 \\
Kenya & 30.22 & 40.07 & $\mathrm{~N} / \mathrm{A}$ & 38.52 & 42.20 & 54.10 & $\mathrm{~N} / \mathrm{A}$ & $\mathrm{N} / \mathrm{A}$ \\
Mauritius & 47.49 & 46.73 & 55.31 & 71.01 & 81.40 & 88.33 & 92.76 & 95.70 \\
United States & 92.19 & 94.75 & 74.74 & 75.56 & 94.18 & 95.71 & 95.49 & 97.61 \\
China & 35.58 & 34.72 & 42.58 & 56.58 & 61.25 & 74.58 & 91.34 & 94.30 \\
Nigeria & 15.31 & 26.54 & 23.89 & 24.57 & 28.73 & 34.90 & 48.54 & 53.74 \\
India & 32.09 & 45.68 & 45.53 & 47.81 & 57.42 & 68.41 & 73.97 & $\mathrm{~N} / \mathrm{A}$ \\
Netherlands & 94.14 & 125.11 & 132.65 & 122.52 & 120.56 & 129.37 & 135.47 & $\mathrm{~N} / \mathrm{A}$ \\
Norway & 94.95 & 109.48 & 116.57 & 114.28 & 113.19 & 112.51 & 112.99 & $\mathrm{~N} / \mathrm{A}$ \\
\hline
\end{tabular}

Source: Authors' computation based on data from World Bank Development Indicator

\subsection{Performance of Nigeria's Industrial Sector}

Industrialization plays a key role in growth and human capital development process. Government policies on industrialization in Nigeria have achieved little success. One of the major reasons for this is that most industrialization policies rested on large state-owned enterprises and targeted capital intensive industries.

Manufacturing sector in Nigeria has failed to go through the needed transformation crucial for it to play a leading role in economic growth. The manufacturing sector in Nigeria is very weak, many industries established such as iron and steel, cement, textiles as well as refineries have either shut down or operating below the full capacity. The technology base of the Nigeria's manufacturing sector cannot drive a sustainable growth process. Needed skills are insufficient due to the low quality or slow rate of human capital development. In addition, the sector has faced a huge challenge of infrastructure, mostly related to power and transportation UNESCO (2016). These had led to escalating costs of many manufacturing industries and reduced their competitiveness in the international market. The average manufacturing capacity utilization was below $50 \%$ in most of the years. On average, between 1995 and 1999 it was 31.8\%, there was improvement from 2010 to 2014 , but fell to $48.5 \%$ in 2016 (see table 2).

The industrial index shows some appreciable increase from 1980 to mid 1990s. However, it witnessed a decrease between 1995 and 1999. One of the major reasons for the fall in the industrial index in this period is the high cost of importation of raw materials due to depreciation of domestic currency. Thereafter, marginal increase was observed up to 2016. Although recently, moderate improvements were recorded, the performance of the industrial sector in Nigeria is still below the desired level. 
Table 2. Industrialization Index and Manufacturing Capacity Utilization in Nigeria

\begin{tabular}{lllllllll}
\hline Year & $\mathbf{1 9 8 0 - 8 4}$ & $\mathbf{1 9 8 5 - 8 9}$ & $\mathbf{1 9 9 0 - 9 4}$ & $\mathbf{1 9 9 5 - 9 9}$ & $\mathbf{2 0 0 0 - 0 4}$ & $\mathbf{2 0 0 5 - 0 9}$ & $\mathbf{2 0 1 0 - 1 4}$ & $\mathbf{2 0 1 6}$ \\
\hline $\begin{array}{l}\text { Industrialization } \\
\text { Index }\end{array}$ & 106.16 & 122.8 & 158.94 & 136.38 & 145.68 & 151.32 & 157.46 & 158.5 \\
& & & & & & & & \\
\hline $\begin{array}{l}\text { Manufacturing } \\
\begin{array}{l}\text { Capacity } \\
\text { Utilization }\end{array}\end{array}$ & 57.4 & 40.7 & 37.6 & 31.8 & 49.18 & 43.35 & 55.82 & 48.5 \\
& & & & & & & &
\end{tabular}

Authors' computation based on data from CBN Bulletin

\subsection{Nigeria's Economic Growth}

Economic growth in Nigeria has not been sustainable. For instance, the average annual growth rate of real GDP between 1980 and 1984 was $-3.4 \%$ (see figure 2). This negative growth occurred a decade after the oil boom era of 1973. Further, low GDP growth was recorded during the Structural Adjustment Programme (SAP). Under the SAP Nigeria's government reformed its foreign exchange system, trade policies, and business and agricultural regulations. Notwithstanding, economic growth after the SAP was only a little higher than they were in the early 1980 .

Improvement in the economic growth was observed between 2000 and 2010 . Some of the policies of the government after the return of democracy in 1999 were geared towards stimulating growth through the attraction of Foreign Direct Investment and the promotion of export. As part of the economic reform programs in this period, Nigerian government introduced the National Economic Empowerment and Development Strategy (NEEDS). The objective of the NEEDS was to increase the standard of living through varieties of reforms, such as, privatisation, deregulation and liberalisation. Nigeria's economy responded positively to some of these initiatives of the government. On average, between 2000 and 2004 economic growth was $11.52 \%$. Since the fall in oil price in the mid-2014, Nigeria's economy growth trajectory has been downward. The Nigerian economy continues to face serious macroeconomic challenges and was in a recession for the first time in decades in 2016. Gross domestic product (GDP) growth for 2016 stood at $-1.5 \%$ (Africa Economic Outlook, 2017).

Figure 2. Nigeria's Economic Growth

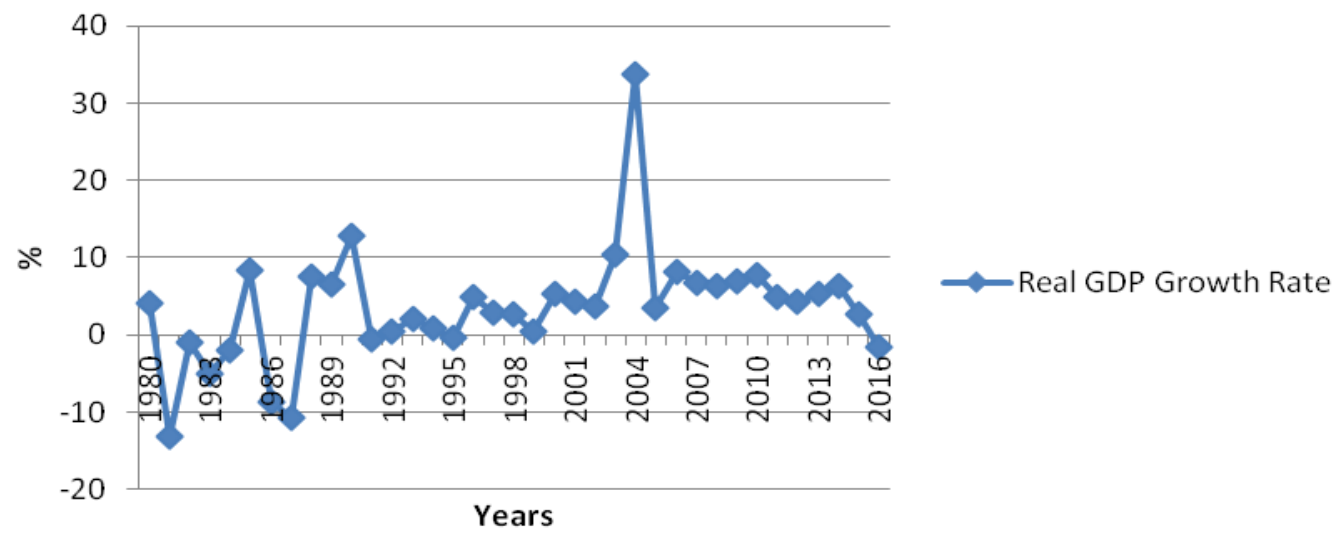

Source: Authors' derivation based on data from World Development Indicator

\subsection{Theoretical framework}

The development of new growth theories is traceable to Lucas (1988) and Romer (1990). Lucas (1988) takes human capital as a factor of production possessing skills with rivalry and excludability nature. The general notion of the theory of Romer (1990) is that human capital involves 'knowledge' and 'ideas' possessing non-rivalry nature even though is partly excludable.

In Romer (1990), endogenous growth occurs as a result of accumulating technology (or knowledge) and thus establishing a relationship between the level of human capital and growth. In 
Lucas theory, which is based on non-decreasing marginal returns, human capital formation itself creates endogenous growth. By implication, for growth to be achieved, it requires same effort to produce an extra unit of human capital without considering the level of human capital. Other choices exist such as increasing quality of human capital over time and knowledge transfer from generation to generation (L'Angevin and Laib 2005). These are in most cases not accounted for thus creating a gap in the model of Romer (1990).

A unique feature of Lucas (1988) theory is that human capital is seen as a factor of production so that constant or increasing marginal returns to human capital accumulation can determine endogenous growth. However, growth becomes endogenous only if there are constant or increasing returns thus making Lucas-Uzawa model (Lucas 1988; Uzawa 1965) to likely be applicable to economic development.

We consider the standard equation where per capita formation exists with human capital as input. Given non-decreasing returns and assuming constant returns to scale:

$h_{c_{t}}=h_{c_{t}} \gamma\left(1-u_{t}\right)-\delta h_{c_{t}}$

Where $h_{c_{t}}$ denotes increase in capital stock, and $\delta$ measures its depreciation. The $\gamma\left(1-u_{t}\right)$ denotes human capital formation with $\gamma$ being a technical parameter that indicates possible factors influencing the efficiency of investment in human capital and $\left(1-u_{t}\right)$ represents the time spent on human capital accumulation. Independent of its level, equation (1) may be written as:

$$
\frac{\dot{h_{c_{t}}}}{h_{c_{t}}}=w_{h}=\gamma\left(1-u_{t}\right)-\delta
$$

Equation (2) indicates growth of the per capita human capital stock which can be regressed on the time spent on acquiring human capital and the constant term represented by the depreciation. On the overall, there tends to be a link between the per capita human capital growth and the time spent for the formation of human capital. Marginal returns exist given that $\gamma$ is positive, constant or increasing. In equation 2 which assumes constant returns, $\gamma$ is positive. Without constant marginal returns, then this equation transforms into

$$
\frac{h_{c t}}{h_{c t}}=w_{h}=\gamma\left(1-u_{t}\right)^{\gamma-1}-\delta
$$

Where $\gamma>1$ indicates increasing returns, $\gamma<1$, diminishing returns and $\gamma=1$, constant returns.

The endogenous growth models developed in most cases explain little about the framework for analysing problems relating to growth in less developed economies. A feature of these economies is the presence of abundance and deficiency in terms of wealth simultaneously. Just as there are the rich individuals in possession of capital so there are the poor with little income and thus less strength to save and invest in both physical and human capital. This is the case of dualism in which the rich and the poor coexist.

On the basis of the dualism under discussion, we consider the rich and the poor individuals existing in an economy. We equally consider the involvement of these individuals in the industrial 
sector in which the workers are employed in a single aggregative sector that produces a single good. The individuals invest in human capital employed in the production sector. Human capital in this case refers to the set of specialised skills which accumulate over the period. Such skills possessed by these individuals are not easily substitutable and so the process of capital accumulation defers for the two individuals. While the population size of either individual is normalised to unity, each individual is also assumed to be identical. There are also the assumptions of full employment and perfect competition between labour and capital market.

The profit maximisation rule ensures that single production sector behaves competitively with the employment of labour and capital. The rich individuals help the poor to accumulate human capital and thus a fraction of total time of rich individual $(1-z)$ is deducted by government and hence allocates a fraction of the remaining $z$ in production while a poor individual would allocate $(1-v)$ fraction of total time in production. Suppose $h_{r}$ and $h_{p}$ respectively represent the skill level of the rich and the poor individual in question so that the production function is:

$\left.y=\pi\left(a z h_{r}\right)^{\alpha}(1-\mu) h_{p}\right)^{\beta} k^{1-\alpha-\beta} h_{r}^{\in r} h_{p}^{\in p}$

Where $0<\alpha<1,0<\beta<1$, and $\epsilon_{r}>0, \epsilon_{p}>0$ indicate parameters measuring the magnitude of the effect of human capital of both the rich and the poor individual on production. In terms of input, the production function satisfies the constant returns to scale but increasing returns to scale if we factor in external shocks. $y$ is level of output and the aggregate physical capital which constitutes the physical capital owned by the rich $\left(k_{r}\right)$ and the one owned by the poor ( $k_{p}$ ) individuals is represented by $k=k_{r}+k_{p}$.

We again assume that the mechanism such as education of human capital accumulation for the rich individuals follows that of Lucas (1988) so that human capital accumulation rate is proportional to the time or simply effort put in for such skill acquisition by the rich. Therefore,

$$
\dot{h}_{r}=m(1-a) z h_{r}
$$

Here, $(1-a)$ indicates the fraction of the time (non-leisure) put in to obtaining their own skills level. Also, $0<a<1$ and $m$ is a constant but positive indicating the productivity parameter of human capital formation of rich individuals.

The process through human capital formation take is different for the two groups of individuals. The training conducted by the rich individuals enhances the skill formation of the poor. This is to enable them take part effectively in production process. Given this situation, each rich individual gives out $(1-z)$ fraction of its time in this training while poor individuals spend $u$ fraction of time not for leisure but for learning skills. The integration of the effort level put by the poor individual in learning and the time the rich individuals spend in training together with the external effect associated generally form the additional skill acquired by the poor worker. Thus, this is expressed as: 
$\dot{h}_{p}=\left\{(1-z) h_{r}\right\}^{\lambda}\left(u h_{p}\right)^{1-\lambda-\theta} h_{r}^{\theta}$

With $0<\lambda<1$ and $\theta>0$. If $z=1, \hat{h}_{p}=0$, and so $h_{p}$ steadily becomes low.

Equation (6) demonstrates the relevance of human capital in industrialization in the sense that the skills acquired by the poor individual together with those acquired by the rich would make a substantial impact in the production process. The unified growth theory (Galor, 2011), underlines that the adaptation to the changing technological environment increases the extent of technological progress and role human capital plays in the production process. Thus, industrialization process triggers the gradual recognition of the role human capital plays in this process.

\section{Methodology}

Our baseline model for this paper is rooted from the new theory of growth discussed in the theoretical framework particularly the one traceable to Lucas (1988). This growth theory sees human capital as part of physical person which influences production process through constant or increasing marginal returns. The baseline models are obtained through modification of equation (4) to include other relevant determinants of growth. The linear model specification is:

$$
\begin{aligned}
& g r=\alpha_{0}+\alpha_{1} l t r_{m}+\alpha_{2} l t r_{f}+\alpha_{3} l e_{m}+\alpha_{4} l e_{f}+\alpha_{5} i d_{x} \\
& +\alpha_{6}\left(l t r_{m} * i d_{x}\right)+\alpha_{7}\left(l t r_{f} * i d_{x}\right)+\alpha_{8} p v_{i}+\varepsilon_{1}
\end{aligned}
$$

Where $g r$ is output growth captured by the growth rate of gross domestic product, ltr $_{m}$ is human capital for male captured by the male literacy rate, $l t r_{f}$ indicates human capital for female captured by the female literacy rate, $l e_{m}$ is life expectancy for male, $l e_{f}$ represents life expectancy for female, $i d_{x}$ is industrialization index, $p v_{i}$ indicates poverty incidence, $\left(l t r_{m} * i d_{x}\right)$ captures the interaction between human capital for male and the industrialization index while $\left(l t r_{f} * i d_{x}\right)$ also indicates the interaction between human capital for male and the industrialization index.

The relationship between human capital and industrialization is modelled as follows:

$$
i d_{x}=\beta_{0}+\beta_{1} l t r_{m}+\beta_{2} l t r_{f}+\beta_{3} l e_{m}+\beta_{4} l e_{f}+\beta_{5} p v_{i}+\beta_{6} g r+\varepsilon_{2}
$$

In equation (7), both literacy rate and life expectancy are disaggregated into male and female counterpart. This is to take gender into consideration. Some studies have emphasized the importance of gender components of human capital in growth process (see for instance, Khan 
In equation (7), both literacy rate and life expectancy are disaggregated into male and female counterpart. This is to take gender into consideration. Some studies have emphasized the importance of gender components of human capital in growth process (see for instance, Khan (2015) and Mahdu (2017)). Life expectancy variable is included as a component of human capital. Human capital should accompany knowledge, physical strength and wellbeing to be able to increase output growth. Industrialization index on the right-hand side explains the role of industrialization process plays in growth. The interactive term is to demonstrate whether literacy rate for male or female complements or serves as substitute for industrialization in facilitating output growth in each case. Poverty incidence is included due to the disparity between the rich and the poor individuals and the existence of inequality. Similar definitions go for equation (8) except that industrialization is dependent on literacy rate, life expectancy, poverty incidence and growth in this case. The disturbance terms in the equations are $\varepsilon_{1}$ and $\varepsilon_{2}$ which are independently and identically distributed with mean and variance in parenthesis $\left(0, \delta^{2}\right)$.

We expect that $\alpha_{0}, \alpha_{1}>0, \alpha_{2}>0, \alpha_{3}>0, \alpha_{4}>0, \alpha_{5}>0, \alpha_{8}<0, \alpha_{6}$ and $\alpha_{7}$ may come with ambiguous signs, $\beta_{1}>0, \beta_{2}>0, \beta_{3}>0, \beta_{4}>0, \beta_{5}<0$ and $\beta_{6}>0$

Having passed through the preliminary test, the paper employs the Two Stage Least Square (TSLS) in estimating the relationships in equations (7) and (8) on the basis that endogenous variable serves as exogenous and vice-versa in each case forming a simultaneous equation system. The TSLS uses instrumental variables to estimate the parameters of the models and it involves two distinct stages. TSLS is adopted in this study because it focuses on investigating the concurrent effect of human capital development indicators on growth and industrial productivity. Also, TSLS is used to correct for errors in the dependent variables and independent variables in equations 7 and 8 . The first stage is concerned with finding the portions of the endogenous and exogenous variables attributable to the instruments. It involves estimating an OLS regression of each variable in the model on a given set of instruments. A regression of the original equation with all the variables replaced by the fitted values from the first stage regression is carried out in the second stage. Finally, the coefficients of this regression come out to be the TSLS estimates.

\subsection{Data Sources}

Due to data inadequacy in a specific source, the paper employs various sources of data. Data on life expectancy for each of male and female is obtained from the World Health Organisation (WHO), data on Literacy rate in each case, GDP growth and the poverty incidence data is obtained from the World Development Indicators (WDI) while the industrialization index comes from the Central Bank Statistical bulletin (CBN). The data is collected from 1980-2016, the period of the study.

\section{Literature Review}

\subsection{Theoretical Review}

The Neo-classical growth model of 1950 and 1960 s forms the starting point for the theoretical relationship between human capital and growth. A model of long run growth was developed by Solow (1956). This shows that output is produced by two factors of production, capital and labour. In the steady state, growth in per capita income increases as unexplained technological change per effective labour increases. The constant capital labour ratio equals the constant per-capita income. Solow model concluded that convergence in income per capita across coun- 
tries depends on identical production function, savings rates and labour force growth rates.

Some extensions of the neoclassical growth model include the contribution of Lucas (1988). The model considers reconstructing the neo-classical theory of growth and international trade by adding features that are consistent with the recent economic development. Three models were developed, first, a model emphasizing physical capital accumulation and technological change, a model on human capital accumulation through schooling and a model that deals with human capital through learning-by-doing. Mankiw, Romer and Weil (1992) explore the effect of adding human capital to Solow model, assuming a constant return to scale and same production function for physical capital, human capital and consumption. In the model, the presence of human capital accumulation increases the impact of physical capital on income.

Romer (1994) shows that new growth model differs from the previous models as it explains the effectiveness of labour as knowledge and models its evolution overtime. Human capital differences explain the slow rate of growth and convergence in some economies. In the endogenous growth model, growth is driven by the accumulation of human capital which is acquired through formal education or through on the job learning-by-doing (Connolly, 2004).

The theoretical model of Ramcharan (2004) categorise human capital into unskilled, low skilled and high skilled. In the paper, the composition of human capital stock determines not only the dynamic pattern of educational investment, but the steady state level of educational attainment. Tunrnovsky (2011) present a two-sector linking human capital accumulation and income inequality. The model is based on certain modification of the theories of Uzawa (1965) and Lucas (1988) in which there are two productive factors, unskilled labour and human capital. Each agent has endowment of unskilled labour but has different initial levels of human capital. The model assumes that aggregate human capital generates externality in which the economy can achieve a sustainable balanced growth path. Productivity is increased in the human capital sector which raised the growth rate.

\subsection{Empirical Studies}

The relationship between human capital and growth in both developed and developing economies has been extensively studied and has generated more controversies in the literature. Nonetheless, diverse evidences were obtained from various empirical studies. One reason for these mixed evidences is that the impact of education on industrial development and growth has varied widely across countries because of institutional differences, educational quality and labour markets constraints.

Using a panel dataset covering 19 OECD countries from 1960 to 2000, Vadenbussche, Aghion and Meghir (2006) identify two channels, namely, innovation and imitation through which human capital leads to technological improvements. Two major findings are discernible. First, the growth in OECD countries is due to skilled human capital rather than that of total human capital. Second, skilled human capital has a stronger growth-enhancing effect in the economies which are closer to the technological frontier. The study emphasized the role of skilled human capital in promoting growth through technological progress.

Earlier studies had shown mixed results on the relationship between expenditure on education and economic growth. The effect of public investment in education on economic growth in Korea and Mexico was studied by Kim and Hong (2010). The findings suggest that investment in education should be such that is in line with the Country's industrial policy, which in turn must match with the country's development stage. Curs, Bhandari and Steiger (2011) used panel data from 1970 to 2005 to investigate whether the exclusion of the private higher education system within a state could lead to bias estimate on the relationship between state higher education spending and economic growth. States with large private higher education institutions have a negative relationship on economic growth. However, states with large public education institutions have positive relationships on growth. This implies that public expenditure on education contribute to growth more than private institutions. 
Studies from Africa have shown some insightful findings. Based on sub-Saharan Africa data, Ossadzifo (2019) finds that the quality of human capital promotes manufacturing sector performance. Consequently, manufacturing sector through value added advances economic growth in the region. Das and Drine (2020) test the relationship among technological gap, educational quality, trade openness and growth in Africa. It was found that capacity to absorb new technology is essential for economic growth and development success. However, Africa's poor human capital development and deteriorated infrastructure are the most significant barrier to industrial advancement and technological catch-up. Study conducted by Oyinlola, Adedeji and Bolarinwa (2020) posits that the challenges of sub-Saharan Africa's industrial development are poor human capital development and very low health expenditure. The findings suggest that in an attempt to promote industrial development, it is important for governments in SSA to explore efficiently the revenue from the sale of natural resource towards human capital development and industrial development.

Conrad (2011) posits that human capital accumulation through government spending on education propels economic growth through two channels. The channels through which it affects growth are the manufacturing and service sectors. Using dataset from India, Gopalakrishna and Rao (2012) explore the links between human development and economic growth. The findings suggest that there are inter-regional disparities in human development. The result shows that there is a positive link between public expenditure and human development. The effect of public expenditure on human development is higher than its effect on economic growth.

Fleisher, Li and Zha (2010) assess the effect of physical, infrastructure and human capital on regional growth pattern in China. It was revealed that human capital positively affects output and productivity growth. Both the direct and indirect effects of human capital on total factor productivity were obtained. The direct effect comes from domestic innovation activities, while the indirect impact is a spillover effect of human capital on total factor productivity growth. Teixeira and Fortuna (2010) examine human capital, research and development and trade relationship in Portuguese economy. Using cointegration technique, it was shown that investing in human capital and research and development from knowledge and technology of advanced countries improves economic progress and trade of developing countries.

The importance of cognitive skills of human capital on economic growth was examined by Hanushek (2013). The findings suggest that attention to school quality would make developing countries to be more successful in closing the gaps with developed countries. Further, it was revealed that developing countries can achieve their long run economic performance through school quality. Using panel data from EU countries, Pelinescu (2015) reveal a positive and significant relationship between GDP per capita and innovative capacity of human capital and qualification of employees measured by secondary school education. However, a negative relationship between education expenditure in GDP and GDP per capita was obtained.

Decomposition of human capital into gender has been done by a few studies. Khan (2015) employ Vector Error Correction Model and Johasen cointegration test to examine the impact of female human capital on economic growth in Pakistan. The study divided human capital into gender component. It was found that a long run relationship exist between female human capital and economic growth. The relationship is statistically significant. However, the short run effect of female human capital on economic growth is statistically insignificant. Similarly, Madhu (2017) investigate the impact of female human capital on economic growth in India using the Autoregressive Distributed Lags (ARDL) bound testing approach and Granger causality test between 1970 and 2014. A composite index was constructed for male and female human capital. It was reported that female human capital is statistically significant and affected economic growth positively both in the short run and long run. Nevertheless, male human capital shows a statistically insignificant effect on economic growth. An evidence of a long-run causal relationship from female human capital, male human capital, and physical capital to economic growth was obtained.

Few studies in Nigeria had shown the link between human capital and growth without a detail analysis on the channel of the effect. For instance, Kanayo (2013) explore the error correction 
model technique to investigate the relationship between human capital formation and economic growth in Nigeria. The study established that human capital development through education and capacity building at primary and secondary school has a positive and significant effect on growth. Adejumo, Olomola and Adejumo (2014) study the effect of human capital on industrial growth in Nigeria between 1980 and 2010. It was found that human capital has significant effect on industry value-added. However, the effect of human capital on industrial output remained low.

Using an ARDL methodology, Anyawu et al (2015) report a positive and statistically insignificant effect of human capital development on economic growth in Nigeria. In a similar study, Suliaman et al (2015) investigated the relationship between human capital, technology and economic growth. The ARDL technique was used to determine the existence of long run relationship. Human capital development was proxy by secondary school enrolment and tertiary enrolment. The findings reveal a positive and statistically significant effect of human capital on growth during the period under investigation. Shuaibu and Oladayo (2016) investigate the determinants of human capital development in 33 Africa countries between 2000 and 2013. Some factors that significantly influence human capital include public expenditures on health and education, institutions and economic growth.

Most of the empirical studies in Nigeria had only shown the relationship between human capital, industrialization and economic growth without proper investigation whether gender differences could change the results. This study intends to fill this gap by decomposing human capital into male and female sexes and examine their effect on industrialization and economic growth. The major reasons for dividing human capital into male and female is to determine their contributions to industrialization and growth process in Nigeria. If gender composition matters; hence, human capital development policies would be targeted to accommodate the contribution of male and female to industrialization and growth.

\section{Results and Discussion}

The descriptive statistics shown in table 3 demonstrates that growth rate comes with the highest mean and median values $(6.176,6.467)$ during the period followed by the industrialization index $(4.934,4.982)$. The growth in their mean values may be connected to the previous growth in these variables. Recently, their growth has been retarded owning to some economic imbalances. Their high standard deviations further show their rate of fluctuations over same period. Female literacy rate comes with the lowest mean and median values $(0.408,0.423)$. This could be explained by the reduction in the rates of schooling among the females. The Growth variable is mostly fluctuating around the period as demonstrated by the standard deviation (4.497); this further explains the high growth rates experienced in the past. Female life expectancy variable has the lowest standard deviation (0.046) and thus least fluctuating. Only three variables are positively skewed, namely, growth, female life expectancy and male life expectancy variables during the period. All the variables have positive coefficients of kurtosis demonstrating their normality. However, only female literacy rate and poverty incidence variables are apparently normally distributed.

Table 3: Descriptive Statistics

\begin{tabular}{|c|c|c|c|c|c|c|}
\hline variable & Mean & median & Std dev & skewness & kurtosis & J-B prob \\
\hline $\boldsymbol{G} \boldsymbol{r}$ & 6.176 & 6.467 & 4.497 & 0.400 & 5.136 & 0.018 \\
\hline $\boldsymbol{i d} \boldsymbol{x}$ & 4.934 & 4.982 & 0.174 & -1.393 & 4.282 & 0.001 \\
\hline $\boldsymbol{l} \boldsymbol{e f}$ & 3.885 & 3.858 & 0.046 & 1.107 & 2.728 & 0.022 \\
\hline $\boldsymbol{l e m}$ & 3.854 & 3.821 & 0.057 & 0.821 & 2.047 & 0.062 \\
\hline $\boldsymbol{I t} \boldsymbol{t} \boldsymbol{I t}$ & 0.408 & 0.423 & 0.063 & -0.318 & 1.714 & 0.205 \\
\hline $\boldsymbol{p} \boldsymbol{v i}$ & 0.628 & 0.665 & 0.062 & -0.411 & 1.434 & 0.090 \\
\hline
\end{tabular}

Source: Authors' computation

Next is test for stationarity as observed in table 4. The test equation for all the variables falls under 
constant and linear trend. The Augmented Dickey Fuller (ADF) test shows that only the growth variable is found stationary at its level (this is because the growth rate of GDP is used) and male life expectancy variable is stationary at its second difference. Other variables are stationary at their first differences except for the female life expectancy which is non-stationary. The results meet the condition that most economic variables are stationary at their first differences.

Table 4. Test for stationarity Results

\begin{tabular}{|c|c|c|c|c|c|}
\hline Variable & Test Equation & ADF & t-statistic & Order of integration & Decision \\
\hline$G r$ & $\mathrm{C}$, linear trend & -3.540 & -4.948 & $\mathrm{I}(\mathrm{o})$ & stationary \\
\hline$i d x$ & $\mathrm{C}$, linear trend & -3.581 & -4.541 & $\mathrm{I}(1)$ & stationary \\
\hline lef & $\mathrm{C}$, linear trend & -3.548 & -11.457 & $\mathrm{I}(2)$ & stationary \\
\hline lem & C, linear trend & -3.548 & -1.107 & ------- & non stationary \\
\hline Itrf & C, linear trend & -3.544 & -6.188 & $\mathrm{I}(1)$ & stationary \\
\hline Itrm & $\mathrm{C}$, linear trend & -3.544 & -5.515 & $\mathrm{I}(1)$ & stationary \\
\hline pvi & $\mathrm{C}$, linear trend & -3.544 & -5.504 & $\mathrm{I}(1)$ & stationary \\
\hline
\end{tabular}

Source: Authors' computation

Estimation of the growth and industrial index equations is shown on table 5. Starting from the key explanatory variables for the growth equation, both the male and female literacy rate variables come with positive coefficients as expected. The results further show that knowledge and skills acquired by females (0.998) have more impact on the economy compared to those acquired by the males (0.447). However, coefficient of life expectancy for male (4.918) demonstrates that males become physically active to contribute to the economy as they grow old unlike the female $(-4.224)$. The index of industrialization coefficient (0.533) demonstrates the positive contribution of industrialization on the economy. Industrialization facilitates growth of output and increases market size of a nation. The interactive term coefficient is positive for male literacy rate and industrialization (0.001) implying that knowledge and skills acquired by male complement industrialization to improve growth performance. On the other hand, knowledge and skills acquired by females can substitute industrialization to accelerate growth as shown by the interactive term coefficient (-0.015). However, following the unequal level of literacy rates among the females compared to those of the males, complete substitution may not in isolation lead to growth acceleration unless complemented by other technological supports. Coefficient of poverty incidence variable follows the expected sign (-3.165). Increasing poverty level is highly inimical to growth as both supply and demand sides of the economy are negatively affected.

Table 5: TSLS Regression Results

\begin{tabular}{|c|c|c|c|c|c|c|c|}
\hline Dep. Var. GR & Coeff. & Std error & Prob. & Dep. Var. idx & Coeff. & Std error & Prob. \\
\hline$C$ & -69.284 & 333.860 & 0.837 & $C$ & 246.381 & 160.327 & 0.136 \\
\hline Idx & 0.533 & 2.092 & 0.801 & & & & \\
\hline Lef & -4.224 & 3.027 & 0.175 & Lef & -3.485 & 7.061 & 0.626 \\
\hline Lem & 4.918 & 2.818 & 0.093 & Lem & 3.175 & 7.372 & 0.670 \\
\hline Ltrf & 0.998 & 7.686 & 0.898 & Ltrf & 5.945 & 2.985 & 0.056 \\
\hline Ltrm & 0.447 & 9.290 & 0.989 & Ltrm & -4.210 & 2.228 & 0.069 \\
\hline Itrf_idx & -0.015 & 0.052 & 0.773 & & & & \\
\hline Itrm_idx & 0.001 & 0.063 & 0.989 & & & & \\
\hline pvi & -3.615 & 10.266 & 0.728 & $p v i$ & -15.554 & 34.828 & 0.659 \\
\hline $\operatorname{AR}(1)$ & -0.168 & 0.226 & 0.464 & $A R(1)$ & 0.706 & 0.162 & 0.000 \\
\hline$R^{2}$ & 0.213 & & & & 0.778 & & \\
\hline$D W$ & 1.544 & & & & 1.425 & & \\
\hline Instrument rank & 19 & & & & 17 & & \\
\hline Prob.(J-statistic) & 0.002 & & & & 0.000 & & \\
\hline
\end{tabular}

Source: Authors' computation 
For the industrial index equation, behaviours of the explanatory variables are similar to what occurs in the growth equation, but in this model the industrial index is the dependent variable and growth variable is included among the explanatory variables. The growth variable here essentially explains the role the economy plays in industrialization. As expected the coefficient (0.108) shows that as economy experiences boom, then industrialization is further enhanced through production efficiency. Male literacy rate (-4.210) impact on industrialization process is not as expected. This may be explained by the huge unemployment conditions the economy has long been experiencing. However, female literacy rate impact on the economy as expected. Similar to the growth equation, male life expectancy (3.175) can increase industrialization process as physical strength and activity still continue as the men grow old. Increasing poverty as shown by the coefficient $(-15.554)$ does not in any way improve the process of industrialization in Nigeria.

All the variables explaining industrialization process accounted for about $78 \%$ of the variations in the industrialization process. In both equations, we have added the AR terms to account for serial autocorrelation in the estimation. Autocorrelation in both cases is controlled and is not seen as a major problem particularly in the growth equation where the Durbin-Watson value is 1.54 . Generally, the two models are adequate as demonstrated by the probability of the F-statistic.

\section{Conclusion}

This paper has examined the role that human capital plays in the relationship between industrialization and growth in Nigeria. The role of human capital in industrialization cannot be left out just as industrialization process cannot be left out of the growth process. The income inequality arising from the frequent use of physical capital was checked and hence this necessitated concentration on the human capital resources. Despite this, there still exists a setback in the development of human capital for growth and industrialization in Nigeria. Basic mechanisms through which such capacity building can take are grossly inadequate. This is further worsened by the lingering economic crisis leading to unemployment, low production base, among others. There is therefore the need to identify the general workings of the system as this would serve as a basic foundation to the solution of the economic woes. It's like a system of equation, once one is solved, others get solved.

Therefore, this study employed the Two-Stage Least Square (TSLS) technique to examine the effects of human capital development on industrial development and growth in Nigeria. This study went a step further to examine the effect of male human capital and female human capital on industrial development and growth. It was revealed that female skills acquisition has more effect on the economy than male. Additionally, the result showed that industrial development spurred economic growth in Nigeria.

Government policies should be geared towards developing human capital, especially in the area of improving the literacy rate; as this is essential for industrialization and growth. Since the findings of this study clearly show that female literacy contributes more to industrialization process than male literacy, hence, human capacity development programs should emphasis the development of female skills to enhance industrial development and accelerate growth process in the country.

\section{References}

Adejumo A.V., Olomola P.A., \& Adejumo O.O. (2013). The Role of Human Capital in Industrialization Development: The Nigerian case (1980-2010). Modern Economy, 4, 639-651. http://dx.doi.org/10.1016/0304-3932(94)90047-7.

African Economic Outlook (2017). Entrepreneurship and Industrialization. AfDB

Anyawu S.O, Adam J.A., Obi B., Yelwa M. (2015). Human Capital Development and Economic Growth in Nigeria. Journal of Economics and Sustainable Development, 6(14), 16-26 https://www.iiste.org/Journals/index.php/JEDS/issue/ view/2001

Barro R. J. (2001). Human Capital and Growth. The American Economic Review, 91(2), 12-17. http://doi.org/10.1257/ aer.91.2.12 
Connolly M. (2004). Human Capital and Growth in Postbellum South: A separate but of Economic Theory, 64(2), 363-399. http://doi.org/10.1017/S0022050704002736

Conrad D.A. (2011). The Level-specific Effects of Education on Economic Growth: Evidence from four Caribbean countries. The Journal of Developing Areas, 45, 279-290. http://doi.org/10.1353/jda.2011.0014

Curs B. R., Bhandari B., Steige C. (2011). The Roles of Public Higher Education Expenditure and the Privatization of the Higher Education on U.S. economic growth. Journal of Education Finance, 36(4), 424-441. https://www. jstor.org/stable/23018119

Fleisher B., Li. H. and Zhao M.Q. (2010). Human Capital, Economic Growth and Regional Inequality in China. Journal of Development Economics, 92, 215-231. https://doi.org/10.1016/j.jdeveco.2009.01.010

Galor O. (2011). Unified Growth Theory, Princeton University Press, Princeton, NJ DOI:10.1057/9780230226203.0434.

Galor O. (2005). From stagnation to growth theory. In P. Aghion and S. Durlauf (Eds.). Handbook of Economic Growth. (pp.171-293). Elsevier

Gennaidi N., Porta R.L., Lopez-de-Silanes D., Shleifer A. (2013). Human Capital and Regional Development .Quarterly Journal of Economics, 128 (1), 105-164. http://doi.org/10.1093/qje/qjs050.

Gopalakrishna B.V., Rao J. (2012). Economic Growth and Human Development: The Experience of Indian States. Indian Journal of Industrial Relations, 47(4), 634-644. https://www.jstor.org/stable/23267365

Hanushek E.A and Kimko D.D (2000). Schooling, Labor-force Quality, and Growth of Nations. American Economic Review 90(5), 1184-1208. http://doi.org/10.1257/aer.90.5.1184.

Hanushek E.A. (2013). Economic Growth in Developing Countries: The Role of Human Capital, Economics of Education Review, Accessed http://dx.doi.org/10.1016/j.ecpmedirev

Human Capital Report (2016). Employment, Skills and Human capital, World Economic Forum 2015, Davis-Klosters, Switzerland. http://dx.doi.org/10.1787/5k8zlm5bc3ns-en.

Kanayo O. (2013). The Impact of Human Capital Formation on Economic Growth in Nigeria. Journal of Economics, 4(2) 121-132. http://doi.org/10.1080/09765239.2013.11884972

Khan M.K. (2015). Contribution of Female Human Capital in Economic growth: An Empirical Analysis of Pakistan (1972-2012). Quality and Quantity: International Journal of Methodology, 50(2), 709-728

Kim C., Hong M. (2010). Education Policy and industrial Development: The Cases of Korea and Mexico. Journal of International Area Studies, 17(2), 21-30. https://www.jstor.org/stable/43107206

L'Angevin C., Laib N. (2005). Education et Croissance en France et dans un Panel de 21 Pays de OCDE, Document de travail, Direction des etudes et syntheses economiques G2005-08, INSEE, Paris. http://www.epsilon.insee. fr:80/jspui/handle/1/5870.

Lucas R.E. (1988). On the Mechanics of Economic Development. Journal of Monetary Economics, XXII, 3-42. https:// doi.org/10.1016/0304-3932(88)90168-7

Mankiw N.G., Romer D., Weil D.N. (1992). A Contribution to the Empirics of Economic Growth. The Quarterly Journal of Economics, 107(2), 407-437. http://hdl.handle.net/10.2307/2118477

Madhu S. A. K. (2017), Does Female Human Capital Contribute to Economic Growth in India? An Empirical Investigation. International Journal of Social Economics, 44(11), 1506-1521. https://doi.org/10.1108/IJSE-10-2015-0272

Ossadzifo K. (2019), Industrialization and Economic Growth in Sub-Saharan Africa: The Role of Human Capital in Structural Transformation. Journal of Empirical Studies, 5(1), 45-54. https://doi.org/10.18488/ journal.66.2018.51.45.54

Oyinlola M.A., Adedeji A.A., Bolarinwa M.O. (2019). Exploring the Nexus Among Natural Resource Rents, Human Capital and Industrial Development in the SSA region. Economic Change and Restructuring 53, 87-111. https://doi. org/10.1007/s10644-018-09243-3

Pelinescu E. (2015). The Impact of Human Capital on Economic Growth. Procedia Economics and Finance, 22, $184-190$. https://doi.org/10.1016/S2212-5671(15)00258-0

Ramcharan R. (2004). Higher or Basic Education? The Composition of Human Capital and Economic Development. IMF Staff Papers, 51(2), 309-326. https://doi.org/10.5089/9781589063235.024

Romer P.M. (1990). Endogenous Technological Change. Journal of Political Economy, 98(5), 71-102. https://doi. org/10.1016/j.najef.2021.101392.

Romer P.M (1994). The Origins of Endogenous Growth. The Journal of Economic Perspectives, 8(1), 3-22. https://doi. org/10.1257/jep.8.1.3 
Shuaibu M., Oladayo P.T. (2016), Determinants of Human Capital Development in Africa: A Panel Data Analysis, Oeconomia Copernicana, 7(4), 523-549. https://doi.org/10.12775/OeC.2016.030

Solow R.M. (1956). A Contribution to the Theory of Economic Growth. The quarterly journal of economics, 70(1), 65-94. https://doi.org/10.2307/1884513

Sulaiman C., Bala U. Tijani B.A., Waziri S.I., Maji I.K. (2015). Human Capital, Technology and Economic Growth: Evidence from Nigeria. International Economics, 5(4). https://doi.org/10.1177\%2F2158244015615166

Teixeira A.A.C., Fortuna N. (2010). Human Capital, R\&D, Trade and Long-run Productivity. Testing the Technological Absorption Hypothesis for the Portuguese Economy, 1960-2001. Research Policy, 39, 335-350. https://doi. org/10.1016/j.respol.2010.01.009

Turnovsky S.J. (2011). The Accumulation of Human Capital and Income Inequality in a Two-sector Economy. Journal of Human Capital, 5(4), 418-452. https://www.journals.uchicago.edu/doi/abs/10.1086/663169

UNESCO (2016). The Role of Technology and Innovation in Inclusive and Sustainable Industrial Development. Industrial Development Report, 2016.

Uzawa H. (1965). Optimal Technical Change in an Aggregative Model of Economic Growth. International Economic Review, 6(1), 18-31. https://doi.org/10.2307/2525621

Vandenbussdie J., Aghion P., Meghir C. (2006). Growth Distance to Frontier and Composition of Human Capital. Journal of Economic Growth, 11(2), 97-127. https://doi.org/10.1007/s10887-006-9002-y

WDI (2016). World Development Indicator Database. World Bank. https://doi.org/10.1596/978-1-4648-0683-4

\section{AUTHORS}

Jimoh Saka. PhD in Economics with interest in International Economics, Econometrics and Development Economics.

Dayo Benedict Olanipekun. PhD in Economics with interest in International Economics and Development Economics.

Conflict of interest

No potential conflict of interest is reported by the authors.

\section{Funding}

No financial assistance from parties outside this article.

\section{Acknowledgments}

$\mathrm{N} / \mathrm{A}$ 